\title{
Contribution of Bycatch in Gillnet Fishery of Saroda Reservoir, Kabeerdham District, Chhattisgarh (India)
}

\author{
K. Anirudh*, J.K. Jakhar and H.K. Vardia \\ Department of Fish Harvest and Post-harvest Technology College of Fisheries Kawardha, \\ Chhattisgarh Kamdhenu Vishwavidyalaya, Chhattisgarh - 491995, India \\ *Corresponding author
}

\begin{tabular}{|c|c|}
\hline & A B S T R A C T \\
\hline & $\begin{array}{l}\text { A comparative study was conducted on different types of gillnets operated in a medium } \\
\text { type Saroda reservoir along the Uttari river in Kabeerdham district. Gillnets mesh size } \\
\text { operated in the reservoir varied from } 20 \mathrm{~mm} \text { to } 210 \mathrm{~mm} \text {. CPUE varied from } 3.70 \mathrm{~kg} \text { to }\end{array}$ \\
\hline $\begin{array}{l}\text { Ke y w o r d s } \\
\text { Saroda Reservoir, } \\
\text { Gillnet, Main catch, } \\
\text { Bycatch. }\end{array}$ & $\begin{array}{l}\text { bycatch. Hanging coefficient of gillnets operated in this reservoir was } 0.7 \text {. The bycatch } \\
\text { from gillnets was } 48.648,5.263,2.277 \text { and } 0.534 \% \text { for various types of gillnets } \mathrm{N} 1, \mathrm{~N} 2 \text {, } \\
\text { bycatch from the gillnet N1 and minor constituent } 0.213 \% \text { from gillnet N4. The bycatch of }\end{array}$ \\
\hline Article Info & $\begin{array}{l}\text { Labeo rohita } 12.126,0.877,0.474 \text { and } 0.106 \% \text {, Cirrhinus mrigala } 6.156,1.154,0.189 \text { and } \\
0.106 \% \text { and undersized Ctenopharyngodon idella } 0.054,0.877,0.474 \text { and } 0.106 \% \text { was }\end{array}$ \\
\hline $\begin{array}{l}\text { Accepted: } \\
\text { 17 September } 2017 \\
\text { Available Online: } \\
\text { 10 November } 2017\end{array}$ & $\begin{array}{l}\text { respectively contributed by gillnet } \mathrm{N} 1, \mathrm{~N} 2, \mathrm{~N} 3 \text { and } \mathrm{N} 4 \text {. The bycatch of Cyprinus carpio } \\
0.054 \% \text { and } 0.189 \% \text {, Hypophthalmichthys molitxix } 1.351 \% \text { and } 0.474 \% \text { was respectively } \\
\text { contributed by gillnets only } \mathrm{N} 1 \text { and N3. One-way ANOVA was carried out and significant } \\
\text { difference was found in bycatch of different gillnets. Gillnet N1 with very small mesh size }\end{array}$ \\
\hline & $\begin{array}{l}\text { had more bycatch in comparison to main catch. Hence, it may be concluded that bycatch is } \\
\text { inversely proportional to mesh size of gillnets. Therefore, it is recommended that smaller } \\
\text { mesh size gillnets shall not be permitted in the reservoir. }\end{array}$ \\
\hline
\end{tabular}

\section{Introduction}

Bycatch is the incidental capture of nontargeted organisms in commercial fisheries, is a growing concern and an important conservation issue (Alverson et al., 1994; Hall and Mainprize, 2005; Harrington et al., 2005; Kelleher, 2005). It is also referred to an incidental catch causing mortality and injuries to the non-target species, is an issue affecting the ecosystem and survival of marine population (Read, 2013). The awareness of bycatch issue attracted a global interest as it is urged to develop international guideline on bycatch management and reduction of discards (FAO, 2014).In general, there are three types of bycatch; normal, cryptic and ghost fishing. Normal bycatch is a non-target species trapped in nets, alive or dead, during hauling process. Cryptic bycatch constitutes of organisms entangled in fishing gears and develops injury and die after trying to escape from the gears (Leland, et al., 2013).

Offlate fisheries are now not only concerned with the sustainability of targeted organisms, 
but also beginning to consider sustainability of catches of non-targeted fauna (Hall, et al., 2000). A number of studies examining bycatch issues have increased exponentially in recent decades (Soykan et al., 2008). However these studies, however, focus primarily on marine systems, leaving freshwater bycatch issues relatively unstudied (Raby et al., 2011).

This is disconcerting given that biodiversity in highly diverse freshwater ecosystems which is declining with overexploitation identified as one of the leading causes (Dudgeon et al., 2006). Gillnets are commonly used in reservoirs. In India several commercial gill net fishery operates in almost all lakes and reservoir systems.

Gillnet is a passive fishing gear with species selectivity and are set for long durations (Hubert, 1996). Bycatch has contributed to the degradation of marine ecosystems (Crowder and Murawski, 1998; Hall et al., 2000; Lewison et al., 2004) and very likely have similar impact on freshwater ecosystems. Therefore, there is a need to determine the extent and consequences of bycatch in freshwater commercial fisheries.

The vast and varied inland water resources contribute immensely to the fisheries in the State of Chhattisgarh. This state has mainly three types of water resource viz. pond/tank (74,300 ha), reservoirs (88700 ha) and river $(3570 \mathrm{~km})$. Fish production from inland water body is of Chhattisgarh is 2.56 lakh tones (2014). Nearly 56\% fish is produced from reservoirs. The total fish production from Kabeerdham district is 9.039 thousand tones. The productivity of this reservoir is 154.76 $\mathrm{kg} / \mathrm{ha}$ (CGSIRD, 2010). The main objectives of this study were to document the total catch, main catch and bycatch from different types of gillnet and comparing the bycatch among different gillnets.

\section{Materials and Methods}

\section{Study area}

The present study was carried out at Saroda reservoir, Kabeerdham, Chhattisgarh, India. It is a small type of dam having area 232 ha. and is located at $21^{\circ} 58^{\prime} 38^{\prime \prime} \mathrm{N}$. The gillnetting is a year round activity in Saroda reservoir. Gillnet operated in this reservoir have different mesh sizes such as $20-60 \mathrm{~mm}$ (N1), 70 - $110 \mathrm{~mm}(\mathrm{~N} 2), 120$ - $160 \mathrm{~mm}(\mathrm{~N} 3)$ and $170-210 \mathrm{~mm}$ (N4). Gillnets of different mesh size group were randomly selected for the collection of catches. Technical details and design features of different gillnets being operated in the Saroda reservoir were documented. The design features includes total length, depth (M), color of twine, size of twine $(\mathrm{mm})$, mesh size $(\mathrm{mm})$, diameter of rope $(\mathrm{mm})$, types and sizes of floats and sinkers, inter distance between two consecutive floats and sinkers $(\mathrm{cm})$. Sampling and identification of species were done during present investigation for quantitative assessment of bycatch. Main catch and bycatch for gillnets were segregated and species identification was done using FAO identification sheets (Fischer and Bianchi, 1981, De Bruin et al., 1994).

\section{Catch effort}

Catch per unit effort (CPUE) was generated for main catch, bycatch and total catch for the landing centers of Saroda reservoir. The CPUE was calculated by using the formula: Catch = CPUE x Effort (Banarjee, 1980). Catch efforts data were collected from the landing centers of Saroda reservoir for gillnets. The catch per unit effort (CPUE) was taken as catches from the net of $1000 \mathrm{~m}$ long, for a soaking duration of 20 hours and the catch was expressed as weight in $\mathrm{kg}$. Estimation of Bycatch, Mean quantity of bycatch and proportion of bycatch to main 
catch were estimated for different gillnets. Mean of bycatch was also calculated (Biradar, 2002). Proportion of bycatch to the main catch was expressed as percentage in terms of weight.

\section{Data analysis}

Analysis of Variance (ANOVA) was carried out for bycatch and main catch for selected gillnets operated in Saroda reservoir to test for variability at $5 \%$ level of significance. Duncan Multiple Range Test was used to separate means. Statistical Package for Social Science (Version 16.0) was used.

\section{Results and Discussion}

Gillnet was found to be a major gear used for harvesting of fishes from Saroda reservoir. A wide variation in design features of gillnets was found (Table 1). The gillnets operated in Saroda reservoir varied in length from $200 \mathrm{~m}$ to $300 \mathrm{~m}$ head rope.

The hanging co-efficient (0.7) and gap between two consecutive sinkers and floats was almost uniform for all the nets operated in Saroda reservoir. The largest mesh size of the net was $210 \mathrm{~mm}$ and the smallest was 20 $\mathrm{mm}$ with operational depth ranging from 8 $10 \mathrm{~m}$.

In Saroda reservoir maximum total catch was contributed by Gillnet N2 whereas least total catch was contributed by gillnet N4. The maximum bycatch $36 \mathrm{~kg}(48.648 \%)$ of total catch get contributed by gillnet N1 whereas the minimum contribution of bycatch was from gillnet $\mathrm{N} 4,0.5 \mathrm{~kg}(0.534 \%)$ of total catch (Table 2).

This variation in main catch and bycatch from the gillnet operated in Saroda reservoir occurred only due to the use of unregulated mesh size of the net. The less mesh size of gillnets results into reduced selectivity and increased bycatch. Presence of undersize fishes such as Labeo rohita, Catla catla, Cirrhinus mrigala, Cyprinus carpio, Hypophthalmichthys molitx and Ctenopharyngodon idella as bycatch in gillnet showed least selectivity of the gillnets. Only three fish species, Labeo rohita, Catla catla and Ctenopharyngodon idella was found as bycatch from the gillnet $\mathrm{N} 2$ and N4. All the five fish species Labeo rohita, Catla catla, Cirrhinus mrigala, Cyprinus carpio, Hypophthalmichthys molitx and Ctenopharyngodon idella was found as bycatch from the gillnet $\mathrm{N} 1$ and $\mathrm{N} 3$. The gillnet N3 have less bycatch $2.4 \mathrm{~kg}$ of total catch $105.4 \mathrm{~kg}$ whereas gillnet $\mathrm{N} 1$ have highest bycatch $36 \mathrm{~kg}$ of total catch $74 \mathrm{~kg}$. The gillnet $\mathrm{N} 1$ have least mesh size followed by N2, N3 and N4. The gillnet N4 have highest mesh size and contributed least bycatch. So, the mesh size of the gill net N1 has to be regulated to reduce proportion of bycatch.

The details on catch per unit effort (CPUE) was estimated for each shot of $100 \mathrm{~m}$ long of different gillnets for a soaking duration of 20 hrs are given in Table 3. The maximum CPUE of bycatch was recorded as $1.80 \mathrm{~kg}$ from the gillnet N1 and minimum was $0.02 \mathrm{~kg}$ from the gillnet N4. A catch per unit effort (CPUE) was generated for main catch, bycatch and total catch for all the gillnets (Table 3).

The statistical analysis of data obtained in this study indicate the significant differences among the main catch and bycatch from all the gillnets (Table 4). Table 4 presents results of one-way ANOVA with Duncan test, comparing the difference in main catch and bycatch at different coasts. The effects of both factors were highly significant with the $p$ value $<0.05$ as found in earlier studies (Anirudh et al., 2014 and 2015). 


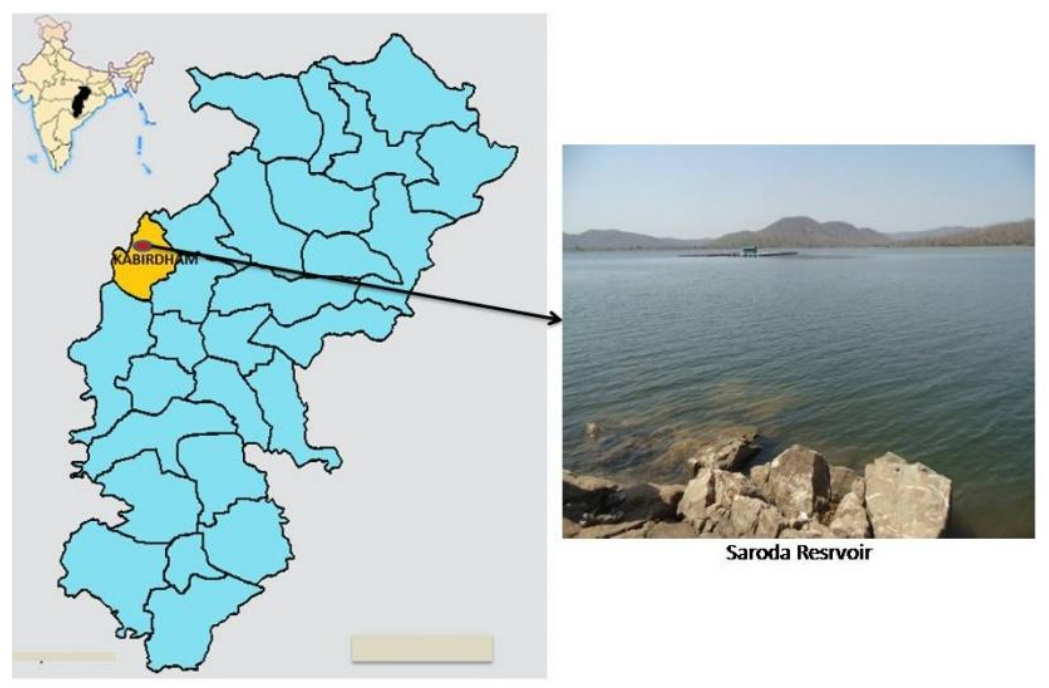

Fig. 1. Study Area (Saroda Reservoir)

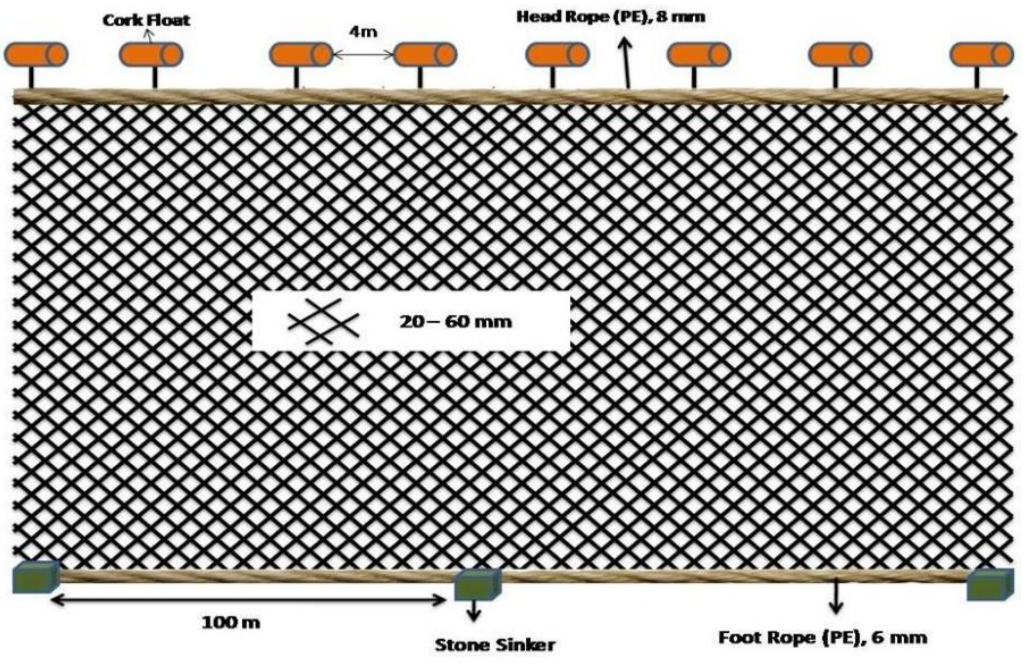

Fig. 2 Gillnet 1 (N1)

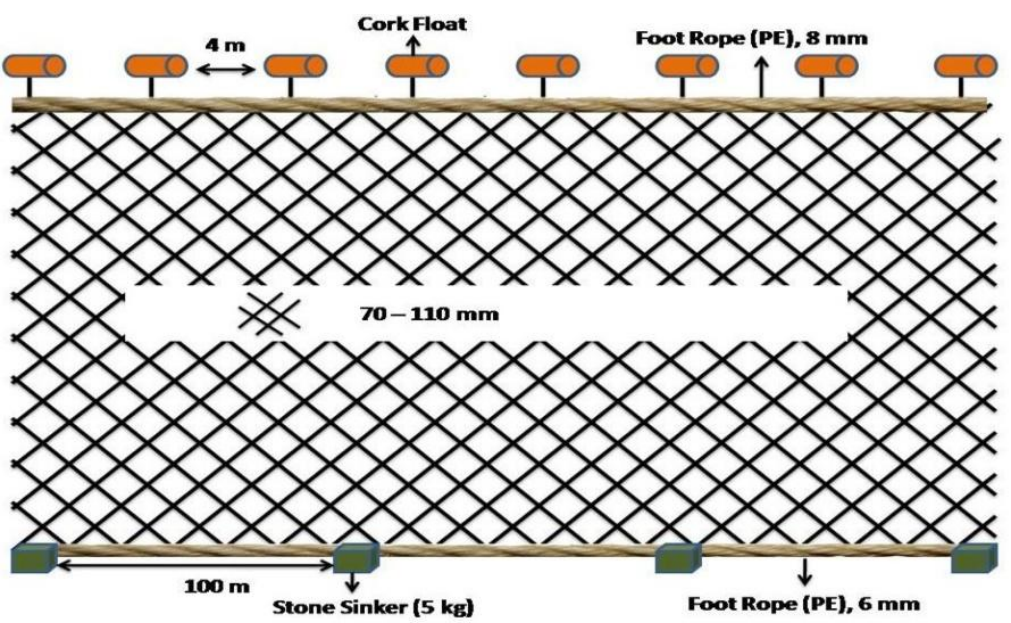

Fig. 3 Gillnet 2 (N2) 


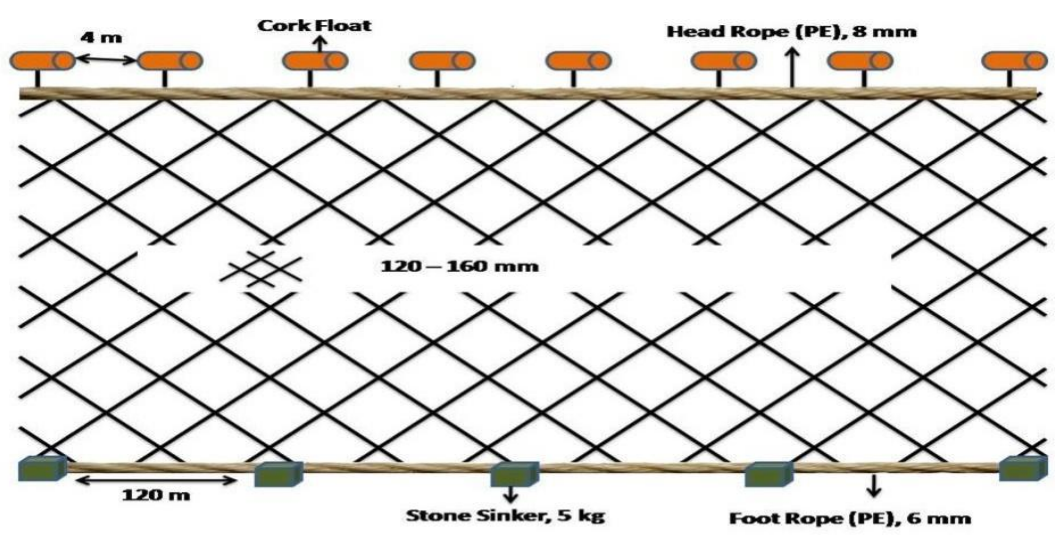

Fig. 4 Gillnet 3 (N3)

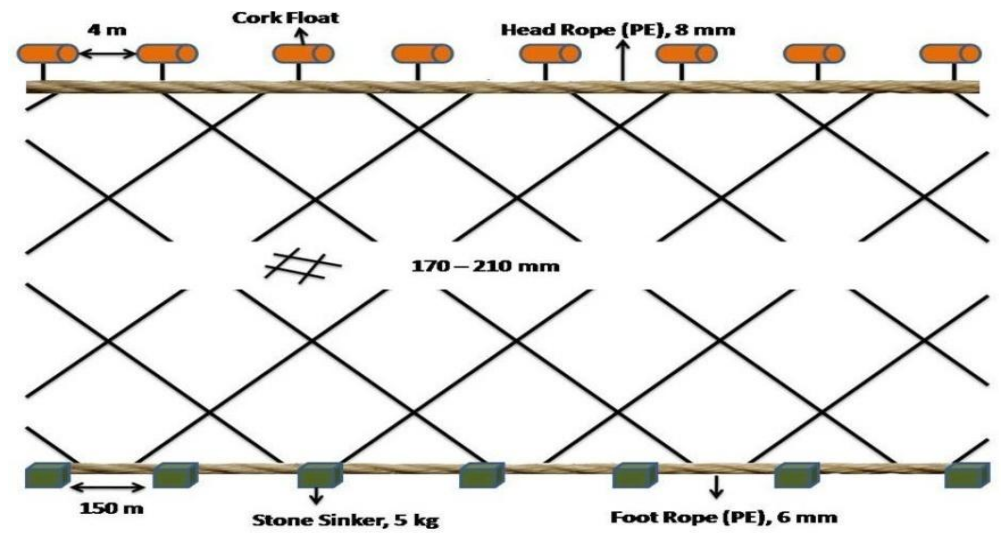

Fig. 5 Gillnet 4 (N4)

Table.1 Design and operational parameters of Gillnets used in Saroda Reservoir, Kabeerdham

\begin{tabular}{|l|c|c|c|c|}
\hline \multirow{2}{*}{ Design Features } & \multicolumn{4}{|c|}{ Gillnets } \\
\cline { 2 - 5 } & Gillnet 1 (N1) & Gillnet 2 (N2) & Gillnet 3 (N3) & Gillnet 4 (N4) \\
\hline Mesh size (mm) & $20-60$ & $70-110$ & $120-160$ & $170-210$ \\
\hline No. of meshes in length & 1600 & 1300 & 900 & 700 \\
\hline No of meshes in depth & 65 & 60 & 52 & 40 \\
\hline Twine diameter (mm) & 1.0 & 1.0 & 1.0 & 1.0 \\
\hline Hanging co-efficient(inner) & 0.7 & 0.7 & 0.7 & 0.7 \\
\hline Netting material & PA & PA & PA & PA \\
\hline Colour of webbing & Light green & white & white & White \\
\hline Head rope and foot rope length (m) & 200 & 200 & 300 & 300 \\
\hline Diameter of head rope (mm) & 8.0 & 8.0 & 8.0 & 8.0 \\
\hline Diameter of foot rope (mm) & 5.0 & 5.0 & 5.0 & 5.0 \\
\hline Rope material & PE & PE & PE & PE \\
\hline Type of float & Thermocol & Thermocol & Thermocol & Thermocol \\
\hline Gap between two consecutive floats(m) & 4.0 & 4.0 & 4.0 & 4.0 \\
\hline Type of sinker (Weight) & Stone $(5 \mathrm{~kg})$ & Stone $(5 \mathrm{~kg})$ & Stone $(5 \mathrm{~kg})$ & Stone $(5 \mathrm{~kg})$ \\
\hline Gap between two consecutive sinkers (m) & 100 & 100 & 150 & 150 \\
\hline Depth of operation (m) & $8-10$ & $8-10$ & $8-10$ & $8-10$ \\
\hline Time of fishing & $5 \mathrm{pm}-8 \mathrm{am} \mathrm{\&}$ & $5 \mathrm{pm}-8 \mathrm{am} \& 10$ & $5 \mathrm{pm}-8 \mathrm{am} \mathrm{\&} \mathrm{10}$ & $5 \mathrm{pm}-8 \mathrm{am} \&$ \\
& $10 \mathrm{am}-3 \mathrm{pm}$ & $\mathrm{am}-3 \mathrm{pm}$ & am $-3 \mathrm{pm}$ & 10 am $-3 \mathrm{pm}$ \\
\hline Duration of fishing (Hours) & 20 & 20 & 20 & 20 \\
\hline
\end{tabular}


Table.2 Mean quantity and proportion of catch and bycatch from Gill nets operated in Saroda Reservoir, Kabeerdham

\begin{tabular}{|c|c|c|c|c|c|}
\hline \multirow[t]{2}{*}{ Species } & \multirow{2}{*}{$\begin{array}{c}\text { Mean } \\
\text { Length } \\
(\mathrm{cm})\end{array}$} & \multicolumn{4}{|c|}{ Mean catch $(\mathrm{kg})$ and Contribution (\%) from Gillnets } \\
\hline & & $\begin{array}{c}\text { Gillnet 1 } \\
(\mathrm{N1}) \\
(20-60 \mathrm{~mm})\end{array}$ & $\begin{array}{l}\text { Gillnet } 2(\mathrm{~N} 2) \\
(70-110 \mathrm{~mm})\end{array}$ & $\begin{array}{c}\text { Gillnet } 3(\mathrm{~N} 3) \\
(120-260 \mathrm{~mm})\end{array}$ & $\begin{array}{c}\text { Gillnet } 4(\mathrm{~N} 4) \\
(170-210 \mathrm{~mm})\end{array}$ \\
\hline \multicolumn{6}{|l|}{ Main Catch } \\
\hline Catla catla & 40 & $\begin{array}{c}5 \\
(6.756 \%) \\
\end{array}$ & $\begin{array}{c}15 \\
(13.157 \%) \\
\end{array}$ & $\begin{array}{c}25 \\
(23.719 \%) \\
\end{array}$ & $\begin{array}{c}70 \\
(75.268 \%) \\
\end{array}$ \\
\hline Labeo rohita & 35 & $\begin{array}{c}7 \\
(9.459 \%)\end{array}$ & $\begin{array}{c}35 \\
(30.701 \%)\end{array}$ & $\begin{array}{c}60 \\
(56.925 \%)\end{array}$ & $\begin{array}{c}20 \\
(21.505 \%)\end{array}$ \\
\hline Cirrhinus mrigala & 28 & $\begin{array}{c}12 \\
(16.216 \%)\end{array}$ & $\begin{array}{c}45 \\
(39.473 \%)\end{array}$ & $\begin{array}{c}7 \\
(6.641 \%)\end{array}$ & $\begin{array}{c}2 \\
(2.150 \%)\end{array}$ \\
\hline Cyprinus carpio & 30 & $\begin{array}{c}3 \\
(4.054 \%)\end{array}$ & $\begin{array}{c}8 \\
(7.017 \%)\end{array}$ & $\begin{array}{c}2 \\
(1.897 \%)\end{array}$ & - \\
\hline $\begin{array}{l}\text { Hypophthalmichthys } \\
\text { molitxix }\end{array}$ & 30 & $\begin{array}{c}1 \\
(1.351 \%)\end{array}$ & $\begin{array}{c}2 \\
(1.754 \%)\end{array}$ & $\begin{array}{c}1 \\
(0.948 \%)\end{array}$ & - \\
\hline $\begin{array}{l}\text { Ctenopharyngodon } \\
\text { idella }\end{array}$ & 35 & $\begin{array}{c}2 \\
(2.702 \%)\end{array}$ & $\begin{array}{c}3 \\
(2.631 \%)\end{array}$ & $\begin{array}{c}8 \\
(7.590 \%)\end{array}$ & $\begin{array}{c}1 \\
(1.075 \%)\end{array}$ \\
\hline Puntius sp. & 12 & $\begin{array}{c}8 \\
(10.810 \%)\end{array}$ & - & - & - \\
\hline \multicolumn{2}{|c|}{ Total Main Catch } & $\begin{array}{c}38 \\
(51.351 \%) \\
\end{array}$ & $\begin{array}{c}108 \\
(94.736 \%) \\
\end{array}$ & $\begin{array}{c}103 \\
(97.620 \%) \\
\end{array}$ & $\begin{array}{c}93 \\
(99.465 \%) \\
\end{array}$ \\
\hline \multicolumn{6}{|l|}{ Bycatch } \\
\hline Catla catla & 24 & $\begin{array}{c}15 \\
(20.270 \%) \\
\end{array}$ & $\begin{array}{c}2 \\
(1.754 \%)\end{array}$ & $\begin{array}{c}0.5 \\
(0.474 \%) \\
\end{array}$ & $\begin{array}{c}0.2 \\
(0.213 \%) \\
\end{array}$ \\
\hline Labeo rohita & 20 & $\begin{array}{c}9 \\
(12.162 \%)\end{array}$ & $\begin{array}{c}1 \\
(0.877 \%)\end{array}$ & $\begin{array}{c}0.5 \\
(0.474 \%)\end{array}$ & $\begin{array}{c}0.1 \\
((0.106 \%)\end{array}$ \\
\hline Cirrhinus mrigala & 22 & $\begin{array}{c}5 \\
(6.756 \%)\end{array}$ & $\begin{array}{c}2 \\
(1.754 \%)\end{array}$ & $\begin{array}{c}0.2 \\
(0.189 \%)\end{array}$ & $\begin{array}{c}0.1 \\
(0.106 \%)\end{array}$ \\
\hline Cyprinus carpio & 18 & $\begin{array}{c}3 \\
(4.054 \%) \\
\end{array}$ & - & $\begin{array}{c}0.2 \\
(0.189 \%) \\
\end{array}$ & - \\
\hline $\begin{array}{l}\text { Hypophthalmichthys } \\
\text { molitxix }\end{array}$ & 20 & $\begin{array}{c}1 \\
(1.351 \%)\end{array}$ & - & $\begin{array}{c}0.5 \\
(0.474 \%)\end{array}$ & - \\
\hline $\begin{array}{l}\text { Ctenopharyngodon } \\
\text { idella }\end{array}$ & 22 & $\begin{array}{c}3 \\
(4.054 \%)\end{array}$ & $\begin{array}{c}1 \\
(0.877 \%)\end{array}$ & $\begin{array}{c}0.5 \\
(0.474 \%)\end{array}$ & $\begin{array}{c}0.1 \\
(0.106 \%)\end{array}$ \\
\hline Puntius sp. & 10 & - & - & - & - \\
\hline \multicolumn{2}{|c|}{ Total Bycatch } & $\begin{array}{c}36 \\
(48.648 \%)\end{array}$ & $\begin{array}{c}6 \\
(5.263 \%)\end{array}$ & $\begin{array}{c}2.4 \\
(2.277 \%)\end{array}$ & $\begin{array}{c}0.5 \\
(0.534 \%)\end{array}$ \\
\hline \multicolumn{2}{|c|}{ Total Catch } & 74 & 114 & 105.4 & 93.5 \\
\hline
\end{tabular}

Table.3 Catch per Unit Effort (CPUE) of Gillnets of Saroda Reservoir, Kabeerdham

\begin{tabular}{|l|l|l|l|l|l|l|l|l|l|}
\hline $\begin{array}{c}\text { Gill } \\
\text { Net }\end{array}$ & $\begin{array}{c}\text { Main } \\
\text { Catch } \\
\text { (Kg) }\end{array}$ & $\begin{array}{c}\text { Effort } \\
\text { (Hrs.) }\end{array}$ & $\begin{array}{c}\text { CPUE } \\
\text { For } \\
\text { Main catch }\end{array}$ & $\begin{array}{c}\text { Bycatch } \\
\text { (Kg) }\end{array}$ & $\begin{array}{c}\text { Effort } \\
\text { (Hrs.) }\end{array}$ & $\begin{array}{c}\text { CPUE } \\
\text { for } \\
\text { Bycatch }\end{array}$ & $\begin{array}{c}\text { Total } \\
\text { Catch } \\
\text { (kg) }\end{array}$ & $\begin{array}{l}\text { Effort } \\
\text { (Hrs.) }\end{array}$ & $\begin{array}{c}\text { CPUE } \\
\text { for } \\
\text { total catch }\end{array}$ \\
\hline N1 & 38 & 20 & 1.90 & 36 & 20 & 1.80 & 74 & 20 & 3.70 \\
\hline N2 & 108 & 20 & 5.40 & 06 & 20 & 0.30 & 114 & 20 & 5.70 \\
\hline N3 & 103 & 20 & 5.15 & 2.4 & 20 & 0.12 & 105.4 & 20 & 5.27 \\
\hline N4 & 93 & 20 & 4.65 & 0.5 & 20 & 0.02 & 93.5 & 20 & 4.67 \\
\hline
\end{tabular}


Table.4 Result of one way ANOVA for main catch, by-catch and total catch for all four types of gillnets operated in Saroda reservoir

\begin{tabular}{|l|c|c|c|}
\hline Gillnets & Main catch Mean \pm SD & Bycatch Mean \pm SD & Total catch Mean \pm SD \\
\hline N1 & $1.8667 \pm 0.35119$ & $1.7333 \pm 0.30551$ & $3.7000 \pm 0.40000$ \\
\hline N2 & $5.3667 \pm 0.45092$ & $0.3000 \pm 0.20000$ & $5.7000 \pm 0.30000$ \\
\hline N3 & $5.1533 \pm 0.41501$ & $0.1233 \pm 0.02517$ & $5.2900 \pm 0.45033$ \\
\hline N4 & $4.6333 \pm 0.47522$ & $0.0200 \pm 0.01000$ & $4.5900 \pm 0.30790$ \\
\hline
\end{tabular}

All values were mean standard deviation (SD) of triplicate analysis. Differ superscripts in the same row indicate significant differences $(\mathrm{P}<0.05)$.

Table.5 Results of one way analysis of variance (ANOVA) comparing the main catch, bycatch and total catch from different five gillnets operated in Saroda reservoir

\begin{tabular}{|l|l|c|c|c|c|c|}
\hline \multicolumn{2}{|c|}{} & $\begin{array}{c}\text { Sum of } \\
\text { Squares }\end{array}$ & df & Mean Square & F & Sig. \\
\hline \multirow{2}{*}{$\begin{array}{l}\text { Main } \\
\text { Catch }\end{array}$} & Between Groups & 23.670 & 3 & 7.890 & 43.547 & .000 \\
\cline { 2 - 7 } & Within Groups & 1.449 & 8 & 0.181 & & \\
\cline { 2 - 7 } & Total & 25.120 & 11 & & & \\
\hline \multirow{3}{*}{ By Catch } & Between Groups & 5.777 & 3 & 1.926 & 57.452 & .000 \\
\cline { 2 - 7 } & Within Groups & .268 & 8 & 0.034 & & \\
\cline { 2 - 7 } & Total & 6.045 & 11 & & & \\
\hline \multirow{2}{*}{$\begin{array}{l}\text { Total } \\
\text { catch }\end{array}$} & Between Groups & 6.908 & 3 & 2.303 & 16.820 & .001 \\
\cline { 2 - 7 } & Within Groups & 1.095 & 8 & 0.137 & & \\
\cline { 2 - 7 } & Total & 8.003 & 11 & & & \\
\hline
\end{tabular}

Significance level of the factors (Source of variation): $p \leq 0.05$

The statistical analysis of data obtained in this study indicate the significant differences among the main catch, bycatch and total catch from all the gillnets operated in Saroda reservoir (Table $5)$.

From this study, author suggests that mesh size of gillnet N1 should be regulated in between 80 $\mathrm{mm}$ to $200 \mathrm{~mm}$ to reduce bycatch by enhancing selectivity. The increase in mesh size will help to increase main catch and reduce energy utilization and time consumption during operation of gillnet in Saroda reservoir. Such studies however, need to be done in other reservoirs too but till then mesh regulation may be extended to all reservoirs uniformly.

\section{Acknowledgement}

The authors would like to thank Dean, College of Fisheries, Kawardha, Chhattisgarh for his kind support in every part of this work. The authors also like to thank all the teaching and non-teaching staff of college of fisheries Kawardha, staff of fisheries department for their valuable guidance and help.

\section{References}

Alverson, D. L., Freeberg, M. H., Pope, J. G. \& Murawski, S. A. 1994. A global assessment of fisheries bycatch and discards. FAO Fish. Tech. Pap. No 339. Rome: FAO.

Anirudh K., Jakhar J. K., Sundaramoorthy B., and Vardia H. K.. 2015. Bycatch and Habitat Impacts of Lobster Bottom Set Gillnet along Thoothukudi Coast, India. Environment \& Ecology 33 (2): 711-716

Anirudh, K., Jakhar, J. K. and Vardia H.K. 2014. Bycatch analysis of Trammel net along Thoothukudi (Tuticorin) coast, india. The Ecoscan 8(3\&4): 339 - 343.

Banerji, S. K. 1980. The collection of catch and effort statistics. FAO Fisheries circular. p. 730. 
Biradar, R. S. 2002. Basic experimental designs. Course manual fisheries statistics, Central Institute of Fisheries Education, Indian Council of Agricultural Research. pp. 289297.

Campbell, M.J. and Sumpton, W.D. 2009. Ghost fishing in the pot fishery for blue swimmer crabs Portunuspelagicus in Queensland, Australia. Fisheries Research, 95: 246-253. doi:10.1016/j.fishres.2008.09.026.

CGSIRD, 2010. Fishery Sub Sector Study of Chhattisgarh State. Pp. $13-15$.

Crowder, L. B. and Murawski, S. A. 1998. Fisheries bycatch: implications for management. Fish 23: 8-17.

De Bruin, G. H. P. D., Russel, B. C. and Bogusch, A. 1994. The marine fishery resource of SriLanka. Food and Agricultural Organization of the United Nations, Rome. 1-353.

Diaz-Uribe, J.G., Arreguin-Sanchez, F. and Cisneros-Mata, M. A. 2007. Multispecies perspective for small-scale fisheries management: A trophic analysis of $\mathrm{La} \mathrm{Paz}$ Bay in the Gulf of California, Mexico. Ecological Modeling, 201: 205-222.

Dudgeon, D., Arthington, A. H., Gessner, M. O., Kawa- bata, Z., Knowler, D. J., Lévêveque, C., Naiman, R. J., Prieur-Richard, A., Soto, D., Stiassny, M. L. J. and Sulli- van, C. A. 2006. Freshwater biodiversity: importance, threats, status and conservation challenges. Biol. Rev. 81: 163-182.

FAO, 2014. The State of World. Fisheries and Aquaculture 2014. FAO fisheries technical paper, $223 \mathrm{pp}$.

Fischer, W. and G. Bianchi 1981 FAO species identification sheets for fishery purposes. Eastern Central Atlantic; fishing areas 34, 47 (in part). Canada Funds-in-Trust. Ottawa, Department of Fisheries and Oceans Canada, by arrangement with the Food and Agriculture Organization of the United Nations, vols. 1-7.

Hall, M. A., Alverson, D. L. and Metuzals, K. I.
2000. By-catch: problems and solutions. Mar. Pollut. Bull. 41: 204-219.

Hall, S. J. \& Mainprize, B. M. 2005. Managing bycatch and discards: how much progress are we making and how can we do better? Fish Fish. 6: 134-155.

Harrington, J. M., Myers, R. A. \& Rosenberg, A. A. 2005. Wasted fishery resources: discarded by-catch in the USA. Fish Fish. 6: $350-361$.

Hubert, W. A. 1996. Passive capture techniques. In Fisheries techniques. 2nd edn. 157-192. Murphy, B. R. \& Willis, D. W. (Eds). Bethesda: American Fisheries Society.

Leland, J., Butcher, P., Broadhurst, M.K. and Paterson, B.D. 2013. Relative trap efficiency for recreationally caught eastern Australia blue swimmer crab (Portunuspelagicus) and associated injury and mortality discard. Fisheries Research, 147: 304-311.

Lewison, R. L., Crowder, L. B., Read, A. J. and Freeman, S. A. 2004. Understanding impacts of fisheries bycatch on marine megafauna. Trends Ecol. Evol. 19: 598604.

McGoodwin, J.R. 1990. Crisis in the World's Fisheries: People, Problems and Policies. Stanford University Press, Stanford, California, $235 \mathrm{pp}$.

Raby, G. D., Colotelo, A. H., Blouin-Demers, G. and Cooke, S. J. 2011. Freshwater commercial bycatch: an under- stated conservation problem. BioScience 61: 271280.

Read, A.J. 2013. Development of conservation strategies used to mitigate the bycatch of harbor porpoises in the Gulf of Maine. Endangered Species Research, 20: 235250.

Soykan, C. U., Moore, J. E., Zydelis, R., Crowder, L. B., Safina, C. and Lewison, R. L. 2008. Why study bycatch? An introduction to the theme section on fisheries bycatch. Endangered Species Res. 5: 91-102.

\section{How to cite this article:}

Anirudh, K., J.K. Jakhar and Vardia, H.K. 2017. Contribution of Bycatch in Gillnet Fishery of Saroda Reservoir, Kabeerdham District, Chhattisgarh (India). Int.J.Curr.Microbiol.App.Sci. 6(11): 2094-2101. doi: https://doi.org/10.20546/ijcmas.2017.611.247 